\title{
Macroeconomic Stability, Bank Soundness, and Designing Optimum Regulatory Structures
}

\author{
George Kaufman \\ Loyola University of Chicago \\ and \\ Federal Reserve Bank of Chicago, U.S.A.
}

This paper focuses on the strong links between macroeconomic stability and bank soundness and argues that if the first is not achieved the second is not likely either with serious adverse consequences. Instability in banking is most often the result of actions by governments directed at the macroeconomy and banks to achieve short-run goals with little consideration for unintended immediate or longer-term consequences. Without government interference, there is little evidence that the banking system is unstable. This paper develops a framework for designing optimum regulatory structures that, if adopted by countries, will help to reduce instability in their banking systems and thereby also in their macroeconomies (E44, G21,G28).

Keywords: macroeconomic stability, bank soundness, designing optimum regulatory structures.

\section{Introduction}

Macroeconomic stability and banking soundness are inexorably linked. Both economic theory and empirical evidence strongly indicate that instability in the macroeconomy is associated with instability in banking and financial markets and instability in these sectors is associated with instability in the macroeconomy. This relationship does not necessarily suggest that financial instability causes macroeconomic instability, but only that the two often occur together. Indeed, as will be argued later in

*This paper is a shorter version of a longer paper prepared for presentation at a Conference on Financial Reform and Stability: Systemic Issues, cosponsored by the Administrative Staff College of India and the International Monetary Fund, Hyderabad, India March 29-30, 2001. I am indebted to participants at this conference and, in particular, to Mario Blejer (IMF), who served as the discussant, and to the journal referee.

(Multinational Finance Journal, 2004, vol. 8, no. 3 \& 4, pp. 141-171)

(C) Multinational Finance Society, a nonprofit corporation. All rights reserved.

DOI: $10.17578 / 8-3 / 4-1$ 


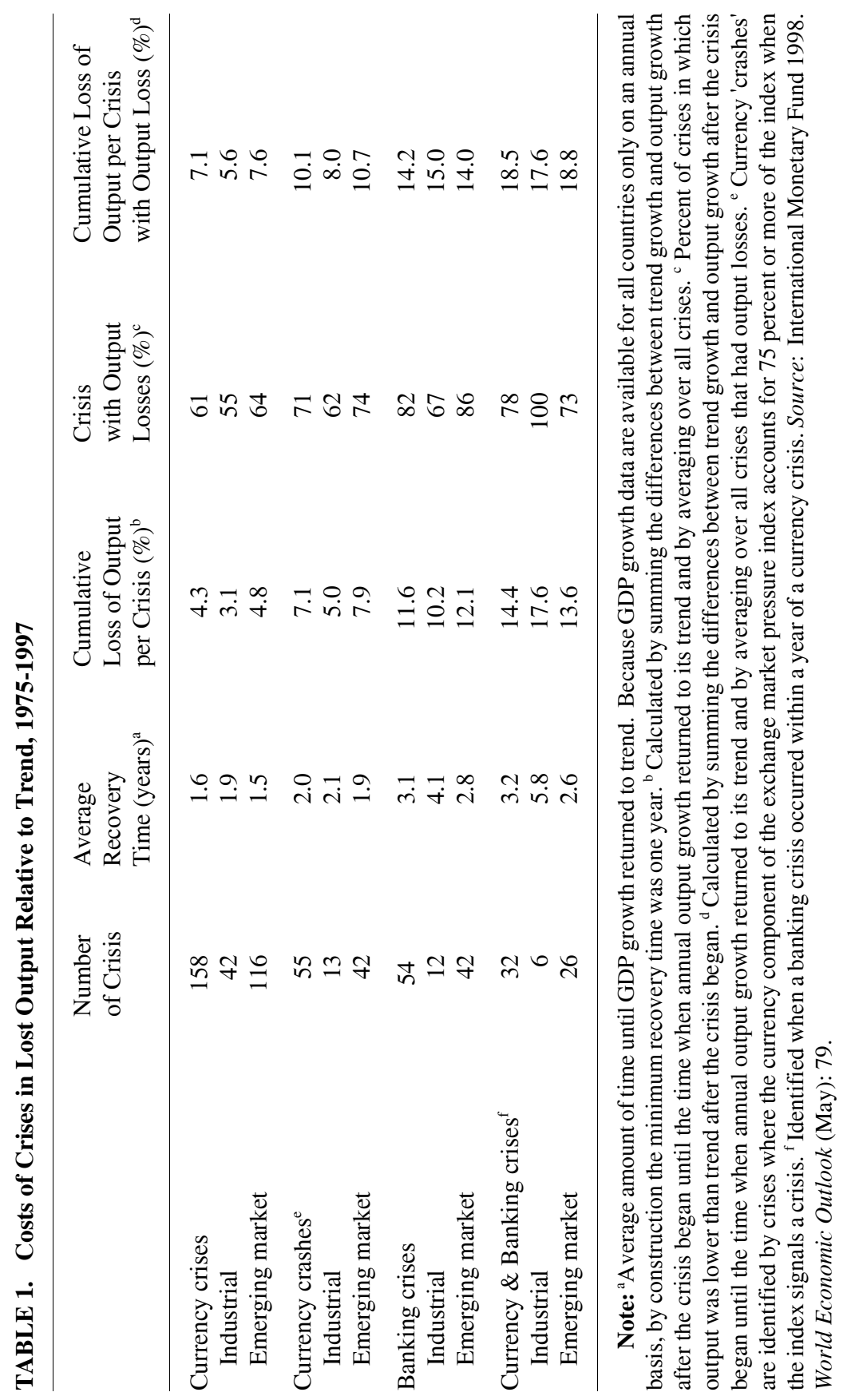


the paper, macroeconomic instability more often than not precedes and is the cause of financial instability, although the latter feeds back and amplifies the former. The costs of banking instability in terms of associated macro instability are well documented. In a survey of 53 industrial and developing countries, the International Monetary Fund (IMF) identified 54 banking crises between 1975 and 1997. Some countries had more than one and some had none. These crises were accompanied by downturns (recessions) in the macroeconomy 82 percent of the time, slightly more often in emerging economies than in industrial economies (table 1). The associated cumulative loss in output from trend averaged near 12 percent, and near 14 percent for countries that experienced any loss in output. The average recovery period to trend output required some three years and was significantly longer in the industrial economies than in the developing economies.

The importance of finance and financial stability on economic development has long been recognized in the economic literature, although it was briefly neglected if not rejected in the 1970s and 1980s until the world-wide round of severe financial crises erupted again; a brief overview of the history of this literature appears in Levine (1997b). The recent evidence that efficient and stable financial systems are prerequisites for economic growth and development has been developed and championed, among others, by Ross Levine and Gerry Caprio and his research team at the World Bank. Most recently, they have argued that "poorly functioning banking systems can impede economic progress, exacerbate poverty, and destabilize economies... [and] well functioning banking systems accelerate long-run economic growth;" see Barth et al. (2001).

Because banking and financial markets in all countries tend to be more regulated by the government than most other industries and banks are even government owned in some countries, including most emerging economies, these authors conclude that "commercial bank regulatory and supervisory policies can significantly affect social welfare ... [Thus] if only policymakers could implement sound policies, commercial bank operations would improve, thereby promoting growth and reducing the likelihood of devastating crises;" see Barth et al. (2001).

In this paper, we attempt to identify what policies these are, what policies, although well-intentioned, are likely to have long-term adverse macro as well as micro consequences, and make recommendations for designing regulatory structures that minimize the probabilities of suffering such adverse effects. 


\section{The Good, the Bad, and the Ugly of Deposit Insurance}

In an attempt to minimize the perceived harm from bank failures, countries in all stages of development almost always, almost as a natural reflex, adopt deposit insurance in some form and/or central bank lender of last resort operations either explicitly through legislation or implicitly through word or deed; see Kane and Klingebiel (2004). These structures are intended to protect some, generally smaller, or all depositors, and possibly other bank stakeholders, including shareholders, against losses at failed institutions. In economies that operate state owned banks (SOBs), this protection is implicitly provided all depositors, as these deposits are effectively viewed as a liability of the government.

But history has shown that official protection can be, and often has been, a flawed and costly policy in the longer-run. Although, by eliminating depositor concern over the value of their deposits, particularly at financially troubled banks, credible deposit insurance and lender of last resort operations can successfully prevent runs on the banking system as a whole, through time, they often have two undesirable side effects. First, without depositor concern for the safety of their funds and with governments tending to underprice the insurance, banks may increase their risk exposures both through their asset and liability portfolios and by reducing their capital ratios to values below what the market would otherwise require, i.e., moral hazard risk-taking behavior by insured banks. Second, in the absence of the threat of bank runs that would force their hands, bank regulators may delay or forbear imposing sanctions on financially troubled institutions and resolving economically insolvent institutions, i.e., poor agency behavior by regulators, for a number of reasons. These include avoiding receiving low grades and public shame for permitting failures to occur on their watch, triggering widespread public fear and uncertainty, having to book losses and use insurance or government funds to pay insured depositors and possibly also some or all noninsured depositors at failed banks, and imposing losses on their friends and political allies who may be uninsured stakeholders at the troubled banks, including shareholders, debtors, and employees. To make forbearance easier, the regulators often disguise or coverup the true magnitude of the banks' problems and even insolvency. As a result, banks are more likely to fail economically, although not legally or officially, and, thus permitted to continue in operation, and more likely to generate larger aggregate losses in the long run. 
TABLE 2. Estimated Transfer Cost of Selected Banking Crises, 1999

\begin{tabular}{llc}
\hline Country & Period & $\begin{array}{c}\text { Estimated Cost/ } \\
\text { GDP }(\%)\end{array}$ \\
\hline United States & $1980 \mathrm{~s}$ & 2.5 \\
Japan & $1990 \mathrm{~s}$ & $20.0^{\mathrm{p}}$ \\
Norway & $1987-89$ & 4.0 \\
Spain & $1977-85$ & 16.8 \\
Sweden & 1991 & 6.4 \\
Bulgaria & $1990 \mathrm{~s}$ & 14.0 \\
Hungary & $1991-95$ & 10.0 \\
Israel & $1977-83$ & 30.0 \\
Mexico & $1990 \mathrm{~s}$ & $12.0-15$ \\
Argentina & $1980-82$ & 55.3 \\
Argentina & $1989-90$ & 13.0 \\
Brazil & $1994-1995$ & $5.0-10.0$ \\
Chile & $1981-83$ & 41.2 \\
Uruguay & $1981-84$ & 24.2 \\
Venezuela & $1994-95$ & 18.0 \\
Turkey & $1982-85$ & 2.5 \\
Finland & $1991-94$ & 8.4 \\
Korea & $1997-99$ & $60.0^{\mathrm{p}}$ \\
Indonesia & $1997-99$ & $50.0^{\mathrm{p}}$ \\
Thailand & $1997-99$ & $45.0^{\mathrm{p}}$ \\
Malaysia & $1997-99$ & $45.0^{\mathrm{p}}$ \\
\hline
\end{tabular}

Note: Includes all depository institutions, costs are to governments and depositors. ${ }^{\mathrm{p}}$ Preliminary. Source: Caprio Jr. and Klingebiel; Lindgren, Garcia and Saal; Rojas-Suarez; and Weisbrod 1998. Wall Street Journal, (October 22): and the author.

At some point, however, the cumulative unbooked losses become too large to be disguised and make further regulatory forbearance politically difficult and recapitalization of the insolvency with public funds a necessity. For many countries, this realization occurs only late in their banking crises and by then at a very high cost. As is shown in table 2, in Argentina, Chile, Korea, Japan, Thailand, Malaysia, and Indonesia the estimated amount of funds transferred from taxpayers to protected depositors in failed banks in recent years exceeded 20 and even 50 percent of their GDP. This transfer cost not only imposes a financial burden on the economy, but redistributes income and creates political unrest. At the same time, the mis-allocation of resources at the operating insolvent banks continues to reduce output in their countries. Indeed, the fiscal transfer costs of banking crises are directly related to the costs of 


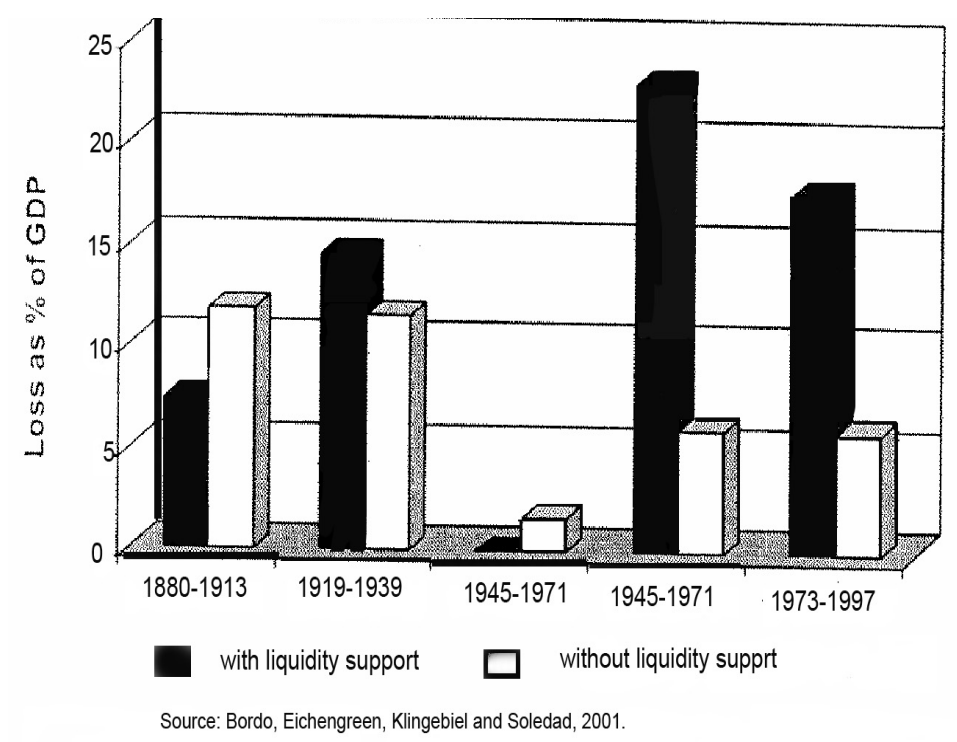

FIGURE 1.-Average Cost of Banking Crises and Liquidity Support.

lost output. The greater the transfer costs, the greater also is the loss in GDP. Moreover, a recent study by Bordo et al. (2001) found that the greater and longer is government support of insolvent banks in the form of liquidity support, blanket guarantees of depositors and other stakeholders, repeated recapitalizations, and forbearance, the greater are the eventual transfer costs and the greater and longer lasting the macro adjustments. This is evident in figure 1 for the average of many countries in the period 1880 to 1997.

Why then is deposit insurance and a safety-net imposed so frequently? Primarily because of the classic problem of time inconsistency in economics in which short-run effects are inconsistent with long-run effects. The good effects (i.e., eliminating runs on the banking system ) occur first and the bad effects (i.e., increasing bank failures and the associated cost of resolution) occur only later. Thus, policy-makers prefer to receive credit for the good immediate effects and hope that the bad effects occur and are recognized only after their terms of office.

Official recognition of the insolvency does not increase the cost or the economic impact. All it does is transform unbooked into booked 
losses of equal magnitude. But because it is the first step required in pursuit of a solution, it may reduce the ultimate potential cost. Unfortunately, official recognition of a large un-book loss is not always easy. The public often shoots the messengers rather than the perpetrators of the bad news. Because in many countries with deposit insurance deposits at operating but insolvent institutions denominated in either domestic or foreign currency in excess of the market value of the banks' assets are effectively government debt, the actual total government debt outstanding may be considerably higher than is officially reported or even perceived. At some point, however, the government's liability grows large enough to be widely recognized and the faith of the public in the ability of the government to service and redeem its outstanding debt is diminished. At this point, depositors will doubt the ability of the government to maintain deposit insurance and will run even on partially or fully insured banks as well as on government owned or controlled banks. In addition, nonperforming loans will no longer be able to be disguised as performing loans and the borrowers' bankrupt status will be forced to be officially recognized. Thus, the delayed adjustments spread beyond the banking system.

\section{Banks and the Macroeconomy}

Although there is wide agreement that banks and the macroeconomy are inexorably linked, the direction of causation is less clear. Inherited popular wisdom is that, in the absence of a government-provided safety-net, banks are inherently unstable and this instability frequently spills over to the macroeconomy. That is, macro instability is often caused by exogenous shocks originating in the banking and financial sectors. According to proponents of this view, fractional reserve banking leads to frequent and unwarranted runs that cause reductions in the money supply and disruptions in the payments system because depositors can neither easily determine the financial strength of their own banks nor differentiate between financially sound and unsound banks. Thus, reductions in reserves are magnified into much larger reductions in money and credit. In addition, because bank borrowers know more about their own financial condition than do their banks, they can finesse banks into making unwarranted loans to them. As a result, banks fuel euphoria-driven irrational overexpansions of credit that bid up asset prices, particularly real estate and equity prices, excessively to 

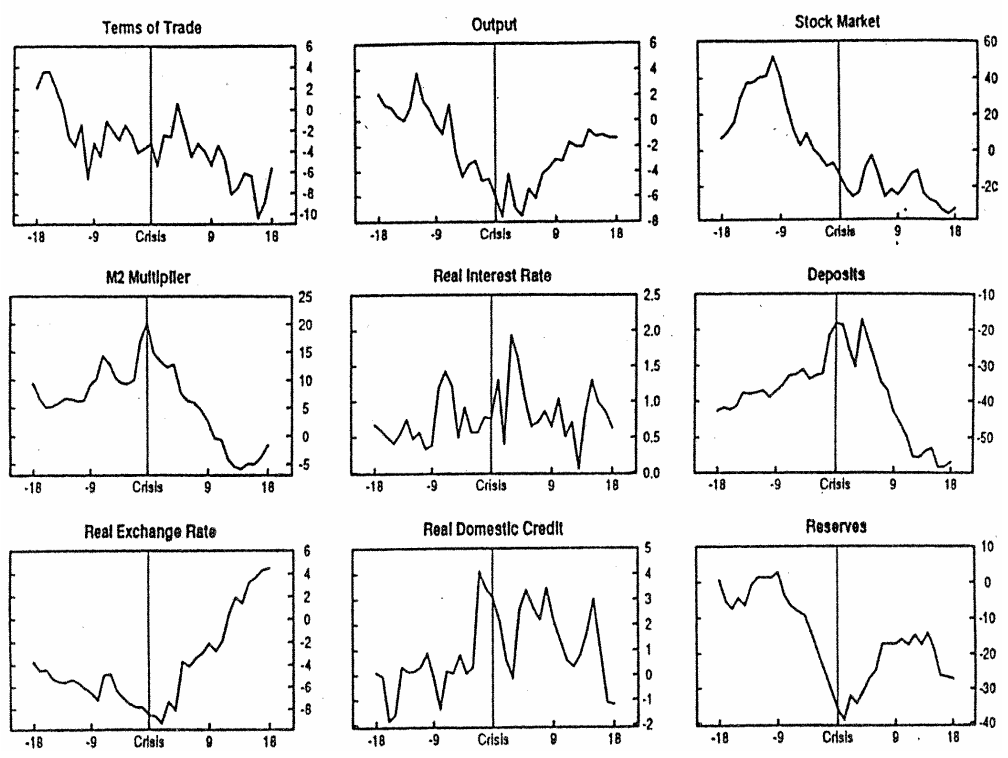

FIGURE 2.-Empirical Regularities During Banking Crises²

levels where they are bound to crash (i.e., fuel asset price bubbles).

However, careful reviews of the literature indicated that there was little if any empirical support for these hypotheses; e.g., Benston et al. (1986) and Benston and Kaufman (1995). In the U.S., at least, fractional reserve banking rarely if at all caused irrational runs that brought down economically solvent banks, and rapid bank credit expansions were driven by sharp increases in the demand for credit based on expectations of higher asset prices originating outside of banking and validated by accommodative expansions in bank reserves by the central bank. Although banks failed more often during macroeconomic downturns, the failures followed, rather than preceded the downturn. Macro problems did not often, if at all, originate exogenously in the banking

2. The real exchange rate and the real interest rate are reported in levels while all other variables are reported in twelve-month changes. All of them are relative to "tranquil" times. Vertical axes are percentages, and horizontal axes the number of months. Source: Graciela L. Kaminsky and Carmen M. Reinhart, The Twin Crises: The Causes of Banking and Balance of Payments Problems, International Finance Discussion Paper no. 5541 (Washington, D.C.: Board of Governors of the Federal Reserve, 1996). 
sector with one important exception - when there was government and regulatory interference.

Basically the same picture is drawn for a larger set of countries by Kaminsky and Reinhart (1996), who developed a number of stylized facts from their investigation of 25 banking crises worldwide between 1970 and the early 1990s. These are plotted in figure 2 . The figure shows that, on average, banking crises are dated a number of months after declines in a country's aggregate output, the stock market, and foreign reserves; shortly after reversals in increases in total credit; and roughly concurrent with downturns in bank deposits.

Government interference can be direct or indirect. Direct interference involves government allocation of loans according to criteria other than market forces, e.g., to state owned enterprises and other favored sectors, firms, or individuals. Direct allocation is most frequent through state owned or heavily controlled banks. It is most frequent in emerging economies, particular basically nonmarket economies, e.g., China and India, although it is also common in many emerging basically market economies, e.g., Thailand, Korea, Indonesia, Mexico, and Malaysia, and even in some industrial countries, e.g., Germany, among others in recent years; see Kaufman (2000). In part, the banks are able to survive badly mis-allocated portfolios because the government ownership or control encourages the perception that the deposits are fully protected, or effectively government securities. Thus, depositors do not run and the banks remain in operation. But, the portfolios in these banks become increasingly concentrated in risky sectors, such as commercial real estate and non-profitable firms.

Governments have also caused banks to fail by requiring them to invest heavily in their bonds, denominated either in domestic or foreign currency, and later defaulting. This effectively translates into a depreciation in the value of all but the fully protected deposits and represents a form of expropriation or confiscation. A major part of the government debt burden is passed through to unprotected depositors.

Indirect interference involves the use of government-sponsored safety-nets that reduce risk monitoring by depositors and increase risk taking by banks. Thus, the banks' credit allocation is likely to differ from that which would result without the safety-net. For example, in the U.S. from the end of World War II through the early 1980s the federal government encouraged savings and loan associations (SLAs) to make long-term fixed-rate home mortgage loans financed by short-term deposits. This maturity mismatch introduced large interest rate risk 
exposures. Thus, when interest rates increased sharply in the late 1970s, the SLAs suffered massive losses and ignited the banking crisis; see Kaufman (1995). In the absence of deposit insurance, depositors would have been unlikely to retain their funds in such institutions and much of the later crises would have been averted. Indeed, in the era before deposit insurance, SLAs made primarily variable-rate mortgage loans which they financed by effectively intermediate-term deposits, so that their interest rate exposure was significantly smaller.

In addition, both direct and indirect government interference incentized the banks to reduce both their cash holdings, as the threat of runs is reduced, and their capital ratios, as depositor monitoring is reduced. As a result, the banks increased both the amount of credit and the percent of their total assets invested in risky assets. Expansions in credit beyond that fueled by the reduction in cash can only occur if the central bank provides the necessary reserves. Such actions contributed further to the runup in asset prices and the eventual bursting of any price bubbles thereby generated.

To the extent that the banking system's asset and liability portfolio size and allocation and capital ratios differ under government interference from what they would be without such interference, financial and likely also real resources are mis-allocated. Through time, this reduces aggregate output below the efficient solution. Moreover, the less efficient portfolio allocation and lower capital ratios are likely to make the banks more fragile than otherwise and more vulnerable to adverse shocks from the macroeconomy.

Although the evidence does not support the hypothesis that exogenous instability in the banking system is a major cause of instability in the macroeconomy, particularly in a world of no or little government interference, it does appear to support the converse. Instability in the macroeconomy spills over into the banking system. Moreover, the resulting poor performance by the banks exacerbates the macro problems. Because financial institutions basically deal in forward contacts, whose profitability hinges greatly on the ability to predict future prices, they do not do well in volatile environments that increase uncertainty and make forecasting more difficult. Banks effectively sell cash for immediate delivery (make loans) and buyback cash for future delivery (receive repayment) on coupon and maturity dates at a fixed interest rate. To reduce their risk exposure, the banks collateralize their loans with either the borrowers' estimated future income and/or the estimated future value of specified assets. If either the realized income 
or realized asset prices fall sufficiently short of the projected values, the borrower may default and generate losses for the bank.

Thus, banks do poorly both when product and asset price inflation accelerate unexpectedly and when inflation decelerates unexpectedly, unemployment increases, and/or aggregate output and income decline unexpectedly. Unexpected accelerations in inflation adversely affects banks that, on average, lend longer-term at fixed-rates than they borrow because nominal interest rates will rise more than expected. This will increase their cost of deposits more than their revenues from loans. Decelerations in inflation and, in particular, bursting of asset price bubbles harm banks because the value of their asset collateral is likely to decline below the value of the associated loans and fuel defaults and losses. Indeed, probably the greatest threat to banking stability in almost all countries is the bursting of asset price bubbles, particularly in real estate and equities. Although banks do not initially ignite the bubble, they finance the increased demand for these assets, so that loans collateralized by these assets account for an important proportion of the earning assets and losses if and when the price bubbles burst are likely to be both large and abrupt. Likewise, increases in unemployment and declines in aggregate output and income lead to loan defaults and losses.

But the damage does not stop here. Bank losses reduce bank capital, driving some banks into insolvency and others to operate with lower than regulatory or, if a safety-net exists, market determined capital ratios. Thus, there will be a reduction in lending from both the disappearance of the insolvent banks and the capital constrained solvent banks. In addition, any new lending extended is likely to be less risky. This behavior gives rise to so-called "credit crunches" that may delay economic recoveries (Bliss and Kaufman [2003]). Kaminsky and Reinhart (1996) also found that banking crises statistically predicted currency (balance of payments) crises, but not vice-versa.

A recent study suggests that banks may also introduce excessive instability both in their own industry and in the macroeconomy by using too short a time horizon in measuring their credit risk exposure; see Borio et al. (2001). They tend to underestimate risk in prosperity and overestimate risk in recessions. As a result, they under-reserve for loan losses, overstate profits and maintain too little capital in booms and over-reserve, understate profits and hold too much capital in busts. As the cost of capital is higher in the latter periods, this pattern forces the banks to curtail credit to rebuild satisfactory internal capital ratios. This crunch could be reduced if the banks were able to draw down their 
higher capital built in good times.

In addition to reduced and less aggressive lending, bank failures may result in losses to depositors and interfere with the smooth and efficient operation of the payments system, when conducted through the banks. Both effects further amplify the problems in the macro-economy. Thus, while in the absence of bad government policy, banks may not be an independent source of instability in the macro-sector, they are a likely transmitter and magnifier of instability in the macro-economy.

\section{Lessons for Bank Stability}

Even if banks per se are not an important independent source of macro instability, they may still be used by governments to tamper with the macro-economy with adverse later impacts and transmit and reinforce macro instability. Therefore, improving bank stability should be an important objective for any country. From this and other recent inquiries into the causes of bank instability, a number of lessons - both dos and don'ts - can be derived. But recent research indicates that the optimal policies are often country specific, depending on income, culture, legal system, property rights, level of education, government credibility, freedom of the press, and so on, so that one size reform need not fit all.

\section{A. Appropriate Macro and Banking Policies}

Macroeconomic stability is both a goal in itself and an important prerequisite for banking stability. Macroeconomic stability may require contra-cyclical monetary and fiscal policies, but not contra-cyclical prudential bank regulatory policy. As noted earlier, during macroeconomic downturns, banks are likely to experience weak capital positions from losses on bad loans and therefore cut back on their new lending. The cutbacks may result in perceived "credit crunches." But in national recessions, nearly all sectors of the economy suffer reductions in output and profitability. The efficient long-run solution is not to reduce bank capital standards or delay or forbear imposing regulatory sanctions on troubled institutions or resolving insolvent institutions in order to encourage lending and jump-start the macro-economy. Although politically appealing, particularly if the regulators are the central bank, which also has responsibility for monetary policy, such a policy will only weaken the banks further by encouraging them to 
extend excessively risky loans and increase the size of the problem in the longer-run. These losses will likely more than offset any short-term gains. More appropriate and lasting policies would include encouraging the entry of new, well capitalized banks including foreign banks, promoting an independent capital market, and stimulating growth in the macro-economy through other means that would encourage the inflow of new capital into banking.

Macroeconomic stability may also be enhanced by introducing prudential banking policies that reduce the adverse impact of macro problems on banks and thereby reduce the likelihood of the banks exacerbating the instability. When not encumbered by excessive government regulation or protected by safety-nets, banks, at least in the U.S., had about the same average failure rate as nonbanks; see Kaufman (1996). The introduction of a poorly structured safety-net caused a major deterioration in their relative performance through time. Banks took increasing risks and regulators practiced increasing forbearance. Among other consequences, bank capital ratios, when measured correctly, become far too low relative to the macroshocks the economy could expect. Partially as a result, the cost of the U.S. banking crises of the 1980s matched that of the 1930s in terms of bank losses relative to GDP and exceeded those of any earlier period; e.g., Kaufman (1995) and Calomiris (1999). Likewise, a recent study reported that since 1973 losses from banking crises as a percent of GDP were nearly four times as great in emerging economies, which provided open-ended financial support to their banks, than countries that provided smaller or no such support; see Bordo et al. (2001). This can be seen clearly from figure 2 .

Because it is unlikely that once introduced either an explicit or implicit government-sponsored safety-net can be completely removed in any country, improvement in bank stability must be achieved by improving the structure of the safety-net to minimize both moral hazard behavior by banks and poor agency behavior by bank regulators. One attempt to do so is the prompt corrective action (PCA) and least cost resolution (LCR) regulatory structure introduced in the U.S. in the Federal Deposit Insurance Corporation Improvement Act (FDICIA) in 1991 at the depth of the banking crisis. To reduce the potential for bank moral hazard behavior, these provisions use a combination of market and regulatory discipline, carrots and stick, and regulatory rules and discretion. First, they require sufficient economic capital for banks to absorb all but totally unforeseen macroeconomic shocks. Then they attempt to mimic the discipline that the market imposes on firms that are 


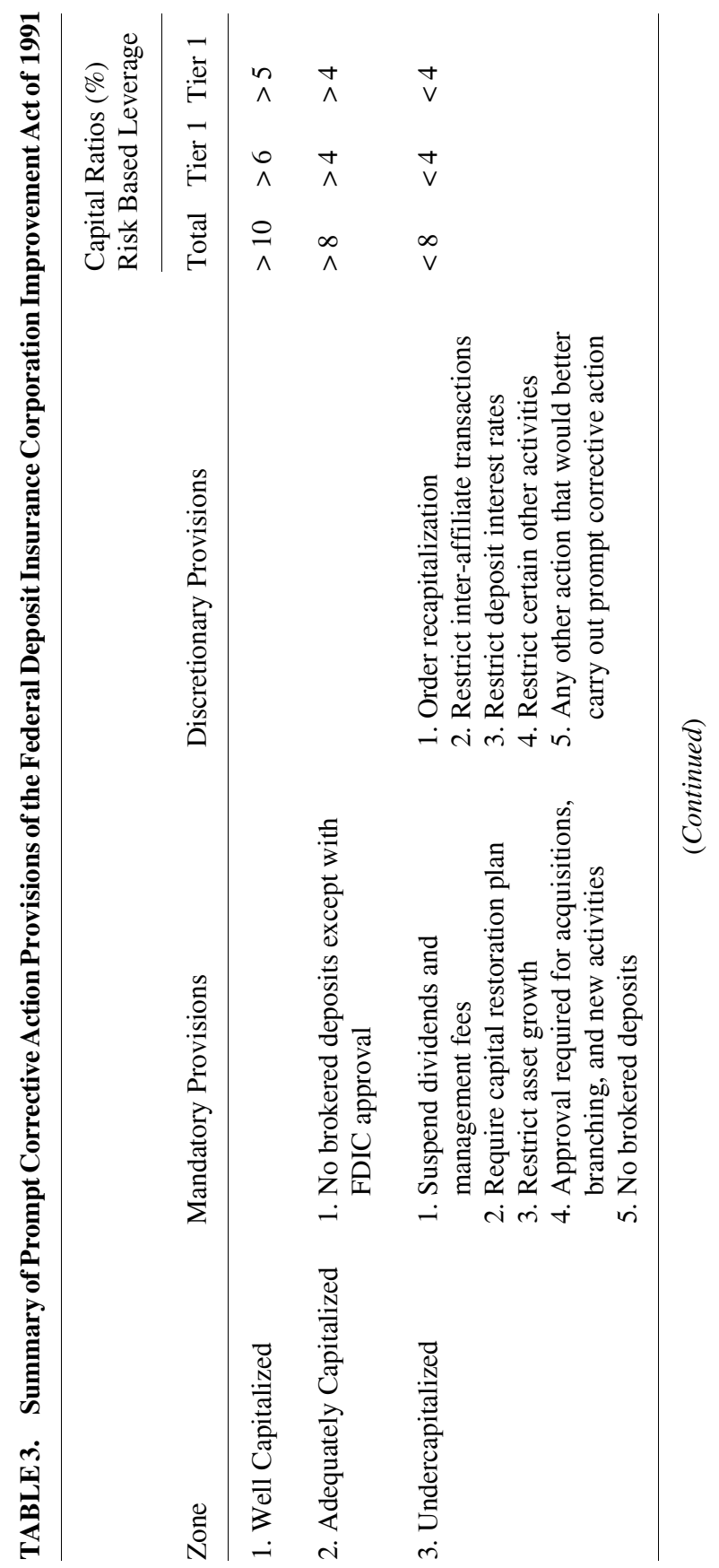


Banking Regulatory Structure Stability and Soundness

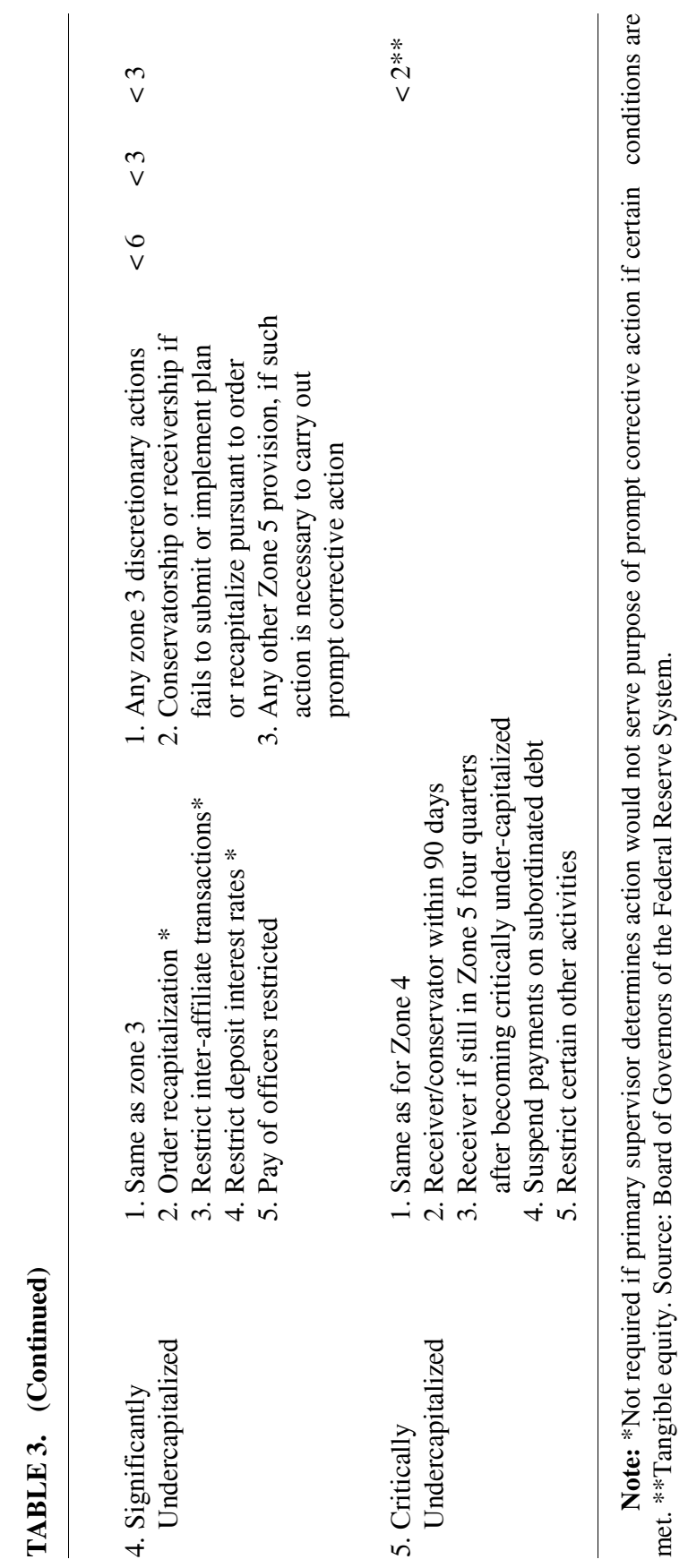


not protected by the safety-net as their financial condition deteriorates. The capital ratio is used as the primary indicator of the bank's financial condition. Multi-capital zones are established; in the U.S., the legislation specifies five such zones. In the highest "well-capitalized" zone, banks are not subject to any special sanctions and may be rewarded by being permitted to engage in broader activities, examined less frequently and so on. But as a bank's capital condition deteriorates, additional and progressively harsher sanctions resembling those imposed by the market are applied. (A summary of the structure of the sanctions currently in effect in the U.S. and the minimum capital ratios for each zone are shown in table 3.) The objective of the structure is to encourage the bank to correct its operations and turn itself around and return to greater profitability and safety.

To reduce the potential for regulators to delay in imposing these sanctions, the structure makes some of the sanctions mandatory. The regulators may first and then must impose certain sanctions. These sanctions are made explicit and publicized. This structure serves to publicize the "rules of the game" to everyone in advance, so that they will shape bank's actions, to make for more equal treatment of all banks, and to provide backup if the earlier discretionary sanctions by the regulators are not effective. Thus, for example, if the capital position of a bank declines to the third tier, classified "undercapitalized," despite the discretionary corrective actions taken by the regulators, the regulators must, among other things, suspend the bank's dividend payments and restrict its asset growth. If the bank continues to deteriorate, the sanctions become still harsher and still more mandatory. Finally, when the bank deteriorates to some small but, at least in book value, positive capital ratio, it must by resolved through sale, merger, or liquidation at the lowest cost to the deposit insurance agency.

The theory underlying this "closure rule" is that if the bank, or any firm, is successfully resolved before its market value equity capital turns negative, losses are confined only to shareholders. Bank depositors and other creditors are fully protected by the remaining assets. Under these conditions, deposit insurance is effectively redundant and only serves as backup when the bank is not resolved quickly enough to avoid negative net worth and losses to depositors. In the real world, a troubled bank may not be able to be resolved before its capital turns negative. But the closer it is, the smaller will be any losses to uninsured depositors and the FDIC. It should be noted that closure or resolution in this context does not mean physical closure, rather it means legal 
closure involving changing owners and management and selling, merging or re-capitalizing the bank. Only if there is insufficient demand for banking services will the institution be liquidated.

To be effective, this structure like almost any reform requires a number of preconditions that are discussed below and in the next section. Without these or similar preconditions, no reform will be effective. Since the introduction of PCA and LCR in 1991, the banking system in the U.S. has performed well. But, despite a downturn in the national macro-economy, there has been no real test of the structure under strain, particularly as it may apply to very large banks. Nevertheless, the early returns appear to be favorable and the structure is increasingly being recommended to other countries as part of a broad program to stabilize their banking systems. But the particulars of the program should be tailored to the unique characteristics of each country; see Kaufman (1997). The more important modifications required depend on the following factors:

Macroeconomic instability

Political instability

Strength of private market and tradition of market discipline

Structure of banking, including solvency and the importance of state owned banks and state controlled banks

Sophistication of bankers

Sophistication of bank regulators, supervisors, and examiners

Sophistication of market participants

Credit culture (credit risk assessments)

Equity culture (willingness to absorb losses)

Bank control on nonbanks and nonbank control of banks

Loan concentration

Quality of accounting information and disclosure

Bankruptcy and repossession laws

Bank reliance on foreign currency deposits

Credibility of the government

More specifically, the following features of the regulatory structure 
need to be tailored specifically to the country:

Values of the tripwires for PCA and LCR

Types of regulatory sanctions

Division between regulatory rules and discretion

Definition of "small" depositors to be protected by insurance

Regulation of foreign currency exposure

Bankruptcy (resolution) process for insured banks

\section{B. Liberalization and Deregulation}

The most efficient allocation of resources is the one generated by an unrestricted price system. This is as true for financial resources as for real resources. Nonmarket allocations may have other appeals, but they reduce and, in the long-run, destabilize macro output. Liberalization or deregulation are generally proposed only when an existing nonmarket process is perceived to be operating poorly and the costs become widely evident and perceived greater than the benefits. Although economists know what the end equilibrium structure looks like, they are notoriously bad at considering the transition process of getting from here to there. This neglect has been amply demonstrated in recent years in a wide range of countries in the high costs of and widespread public dissatisfaction with deregulation not only of banking and financial markets, but of communications, airlines, electricity, and international capital flows. As a result, the intermediary outcomes before the new equilibrium is achieved have often been perceived as worse than the previous nonmarket outcome. Equally important, the blame has often been put on the concept of deregulation per se, rather that on the flawed process of deregulation, where it belongs, and has reduced popular support for deregulation. This has not infrequently halted and even reversed the deregulation process. The transition stage is of immense political, if not economic, importance.

Indeed, a large percentage of banking crises have occurred during or immediately after well intentioned but poorly implemented deregulation of banks, including lifting or removing deposit rate ceilings, granting new lending and investing powers, and liberalizing entry. These changes led to increased failures from increased competition, reduced franchise values, and increased potential for risk and fraud taking, particularly 
when bank managers and supervisors were not brought up to speed simultaneously or market discipline was not permitted to increase to offset the decline in regulatory discipline. Thus, Kaminsky and Reinhart (1996) report that some 70 percent of their 25 banking crises were preceded by deregulation and that financial liberalization was statistically significant in explaining banking crises, although not currency crises. Likewise, Eichengreen and Arteta (2000) conclude "that bank stability in emerging markets is at risk when macroeconomic and financial policies combine with financial deregulation to create an unsustainable lending boom." This suggests that something went dramatically wrong in the deregulation process.

It should be noted that market regulation by itself may not be optimal. All firms in all countries are regulated either by the marketplace or by the government. There is some evidence that a system that permits both forms of regulation in competition with each other may be better than a system that permits only one. In such a dual system, when one form of economic regulation is perceived not to be working well, by whatever criteria, support develops for a change to the other. The market-government regulation life cycle may be depicted as follows:

Market regulation $\rightarrow$ market failures $\rightarrow$ "horror" stories $\rightarrow$ government intervention (regulation) $\rightarrow$ government failures (less frequent than market failures but higher cost) $\rightarrow$ government deregulation $\rightarrow$ market regulation $\rightarrow$ market failures $\rightarrow$...

It may be argued that in economies in which both forms of regulation coexist, the tension between market and government regulation provides protection against both excessive government regulation, on the one hand, and insufficient market regulation, on the other. Such beneficial tension is currently missing in most developing and transitional economies, where state-owned banks and credit allocation through the banking system are important. The optimal mix is likely to be country specific and path dependent.

Thus, if the goal of deregulation of banking is desirable, and it generally is, it must be done correctly. Poorly designed deregulation may be worse than no deregulation. Deregulation should not be started until many of a number of important preconditions are in place. Many are the same or similar to those cited in the previous section for enhancing bank safety. These include: 
Well trained and compensated independent bank regulators and supervisors

Private bankers able and willing to do credit and other risk evaluations and assume the associated risks and potential losses (credit culture)

An equity culture, so that losses as well as gains are privatized and not socialized

Viable property rights and enforcement

Legal processes, including bankruptcy laws and enforceability of laws and regulations

Explicit limited deposit insurance, lender of last resort operations, and other components of a government safety-net under banks

Competition among banks and between banks and capital markets No barriers to the entry of foreign banks

Meaningful government credibility

Enforcement of quality accounting and disclosure provisions

Explicit provisions for regulatory discipline on banks to supplement but not substitute for market discipline, along the lines of prompt corrective action (PCA) under FDICIA in the U.S.

Reasonable macroeconomic stability

Reasonable political stability

Credible government

\section{Post-Resolution Policies to Prevent Loss of Liquidity}

The insolvency of banks is costly to the macro-economy per se, but this cost can be increased or decreased by the regulators by the policies they use in resolving the insolvencies. As noted earlier, the faster banks can be resolved before their economic capital turns negative, the smaller are both losses to depositors and costs to the macro-economy. Credit loss costs may be reduced by both specifying a closure rule that defines legal failure close to economic failure and restricting the ability of regulators to delay resolving institutions after they met the definition of legal 
failure. In addition, the cost of a failure depends on how fast after banks are declared legally failed that both insured and uninsured depositors at these institutions are given access to the current value of their deposits, thereby reducing their liquidity losses.

Delays may occur both because it takes time to obtain the names of qualified insured depositors and the amount of their deposits and to sell the banks assets and collect the proceeds from the receiver and because the government may want to confiscate or expropriate part or all of the deposits; see Kaufman and Seelig (2002). As a result, in many countries, depositor funds are effectively frozen for some time and then often paid in installments only through time as the insurance agency collects the sales proceeds from the receiver and pays the full par value to insured depositors and the pro-rata recovery proceeds to uninsured depositors. The longer the delay, the greater is the loss in liquidity to depositors and the greater is both the actual cost and the public fear of failure. Indeed, the cost of any loss of liquidity from delayed depositor access to their funds may be equal and possibly even greater than the cost to the macro-economy of any loss in the value of the deposits. As a European analyst has recently observed

The issue is not so much the fear of a domino effect whereby the failure of a large bank would create the failure of many smaller ones; strict analysis of counter-party exposures has reduced substantially the risk of a domino effect. The fear is rather that the need to close a bank for several months to value its illiquid assets would freeze a large part of deposits and savings, causing a significant negative effect on national consumption; see Dermine (1996), p. 60.

As a result, depositors may be expected to exert great pressure on the government to delay resolving insolvent banks.

Losses in liquidity from bank failures may be reduced by granting the insurance agency authority to advance payment to both insured and uninsured depositors at failed institutions before the funds are received from the receiver; see Kaufman and Seelig (2002). For insured depositors, the advance would be the full par value of their deposits; for uninsured depositors it would be the pro-rata estimated recovery value, which may be generally expected to be less than the par value. This procedure has been frequently used by the FDIC in the U.S. The FDIC always makes payment on insured deposits within one or two business days after a bank is legally failed and resolved and frequently pays 


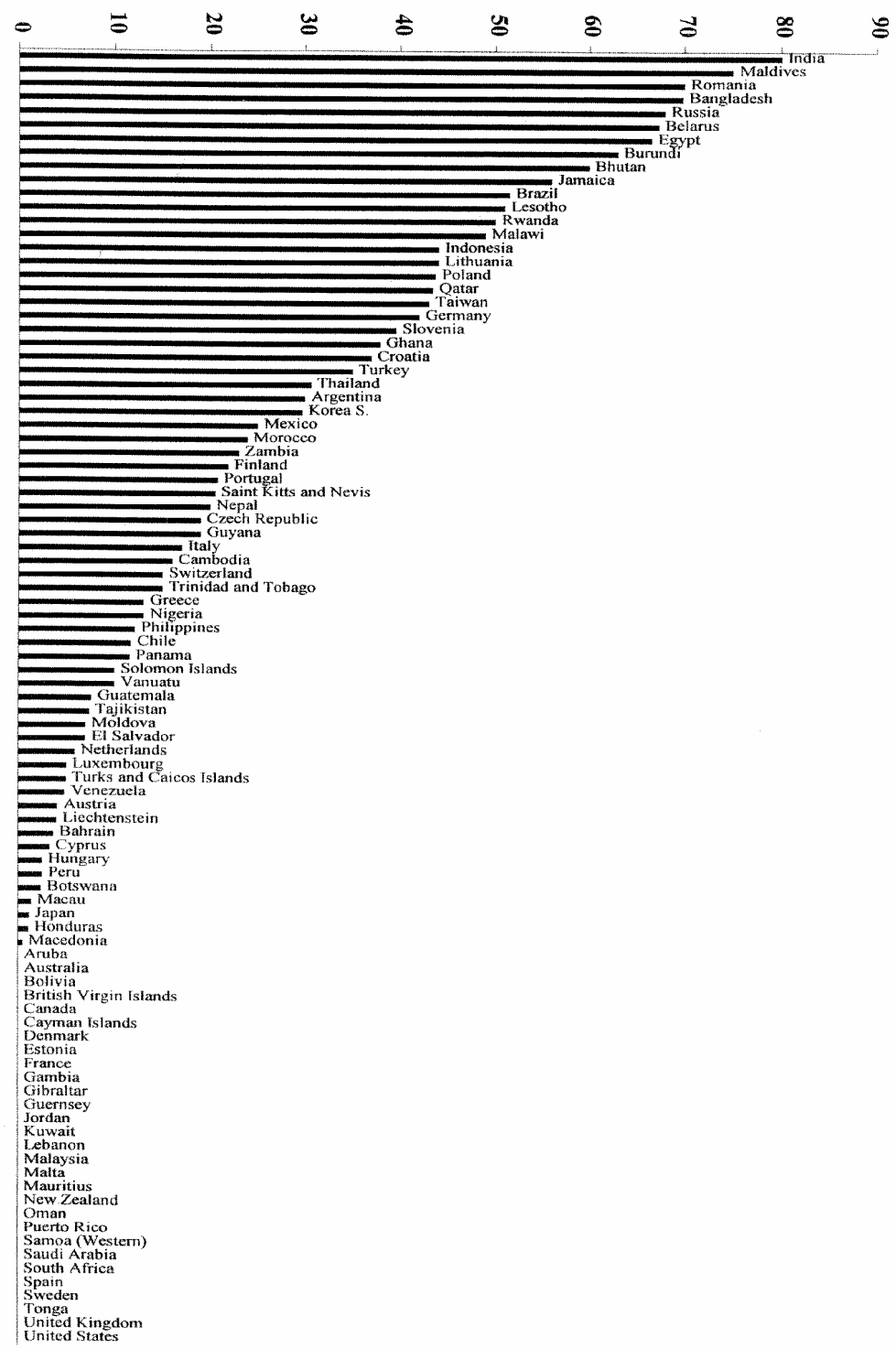

FIGURE 3.-Percent of Total Bank Assets in State Owned Banks ${ }^{3}$

3. Source: Barth et al. (2001); appendix. 
uninsured deposits a conservative estimate of their pro-rata share of the recovery values in the form of an advanced dividend. If this payment turns out after all assets are liquidated to have been too small, additional payments are made. If it were too large, the FDIC absorbs the loss. If, the losses in value for uninsured depositors are relatively small because of the timely implementation of an efficient closure rule, minimizing liquidity losses by advancing payment to depositors makes it easier for regulators to avoid surrendering to "too-big-to-fail" pressures and to resolve insolvent large banks without protecting uninsured depositors. These depositors would then view bank deposits as similar to other short-term but risky assets in which they invest and are willing to suffer limited losses, such as commercial paper and bankers acceptances.

However, for technical reasons, it is not necessarily easy for insurers to advance the necessary funds in a timely fashion, even if they were permitted to do so by law. The records of the resolved bank may not allow a quick determination of either the eligible insured deposits or the estimated recovery value of the assets. To obtain this information quickly it is necessary for the regulators to be familiar with the banks' records before resolution. In the U.S., regulators are able to become familiar with troubled banks before resolution because of the requirements of PCA and LCR. As troubled banks become classified as undercapitalized by PCA criteria, they become subject to closer and more frequent scrutiny by examiners. To the extent that, except in cases of major fraud, large reductions in bank capital do not occur abruptly and catch dedicated supervisors by surprise, which should be unlikely, the examiners should be thoroughly familiar with the particulars of the banks before the date of legal insolvency. Thus, they should be in a position to provide the necessary information to potential bidders for the bank upon its resolution.

\section{Privatize Government Owned Banks}

Government or state owned banks and state controlled banks are important in many countries, particularly in emerging economies although also in some industrial countries, such as Germany. The percent of bank assets owned by the government in a large number of countries is shown in figure 3. But SOBs and SCBs are generally banks in name only; see Kaufman (2000). They are effectively extensions of the government treasury department used to collect savings in order to finance activities that the government wishes to promote but not to 
finance through tax or bond sale revenues. SOB and SCB financing is also often loans in name only. Repayment and market interest rates are often not expected and credit evaluations are not always conducted. Delayed and missed payments are not penalized. As a result, SOBs and SCBs are, on average, far less profitable than their private counterparts and tend to have unusually high percentages of nonperforming assets. Many are economically insolvent. As noted earlier, their deposits, at minimum up to the banks' negative net worth, are effectively unbooked government debt. To obtain an accurate picture of the government's fiscal activities, SOBs and SCBs should be incorporated in the government budget.

Because SOBs and SCBs can continue to operate while insolvent, they mask the underlying problems and permit the government to continue to finance inefficient projects and friends. In time, the system will collapse, but in the shorter-run it could bring big rewards to the government in power and, if the government guesses right on the sectors financed, higher employment and faster economic growth. These banks are not accidents waiting to happen, but accidents that have already happened and are just waiting to be officially recognized and booked. To head off the later and likely larger adverse effects, the SOBs and SCBs should either be privatized as soon as possible or folded into the consolidated government budget and their deposits explicitly booked as government debt. If, as is likely, a number of SOBs are insolvent simultaneously, it may not be feasible to privatize all simultaneously. In this case, triage should be undertaken and those institutions with the largest relative negative net worths recapitlized and privatized first. Because private bidders are unlikely to bid enough to assume all of the negative net worth, government funds will be required to assume the remainder. This is a sunk cost.

But just as deregulation, privatization is not easy to do correctly and is often done poorly, particularly when the primary motivation is to obtain additional revenue for the government budget rather than to change the economic system. For success, the same preconditions as for deregulation must be in place. Equally importantly, the privatization must be complete, including requiring sufficient correctly measured capital to match the capital ratios of similar private institutions in the absence of an underpriced safety-net and a clear, explicit documentation of any remaining government liability, including through deposit insurance. If the required capital standards are insufficient, the banks are highly likely to quickly return to insolvency and SCB status as has recently occurred in Mexico and Russia; see Kaufman (1999). To 
TABLE 4. Financing of Private Nonfinancial Sector by Direct (Capital Market) and Indirect (Banking System) Channels Selected Countries, 1993

\begin{tabular}{|c|c|c|c|c|}
\hline \multirow[b]{2}{*}{ Country } & \multicolumn{2}{|c|}{ Indirect Channel } & \multirow[t]{2}{*}{ Direct Chanel } & \multirow[t]{2}{*}{ Foreign Sources } \\
\hline & Banks & Other & & \\
\hline Brazil & 80 & 20 & - & - \\
\hline Germany & 65 & - & 28 & 7 \\
\hline Hungary & 23 & - & 28 & 49 \\
\hline India & 22 & 34 & 39 & 5 \\
\hline Israel & 52 & - & 42 & 7 \\
\hline Japan & 43 & 24 & 34 & - \\
\hline Korea & 25 & 35 & 37 & 4 \\
\hline Mexico & 91 & 9 & - & - \\
\hline Singapore & 87 & 13 & - & - \\
\hline U.K. & 42 & - & 52 & 6 \\
\hline U.S. & 17 & 21 & 62 & - \\
\hline
\end{tabular}

Note: Source: BIS 1998. The Transmission of Monetary Policy in Emerging Market Economies. 24.

maximize the selling price and minimize public funding of the negative net worth of the banks to be sold, foreign bidders should be permitted with the same restrictions as imposed on domestic bidders.

\section{E. Develop Competitive Banking and Capital Market Sectors}

Efficient banks and financial markets promote macro development, growth and stability. But, as noted, macroeconomic instability can cause bank credit crunches, that may hamper economic recoveries. This bottleneck may be reduced if the economy also had an efficient capital market, so that borrowers can bypass the banks in periods in which they are experiencing problems. The advantage of having two financing channels to direct funds from savers to borrowers rather than only one has also been noted by Greenspan as follows:

Recent adverse banking experiences have emphasized the problems that can arise if banks are almost the sole source of intermediation. Their breakdown induces a sharp weakening in economic growth. A wider range of nonbank institutions, including viable debt and equity markets, are important safeguards of economic activity when banking fail; see Greenspan (1998), p. 8. 


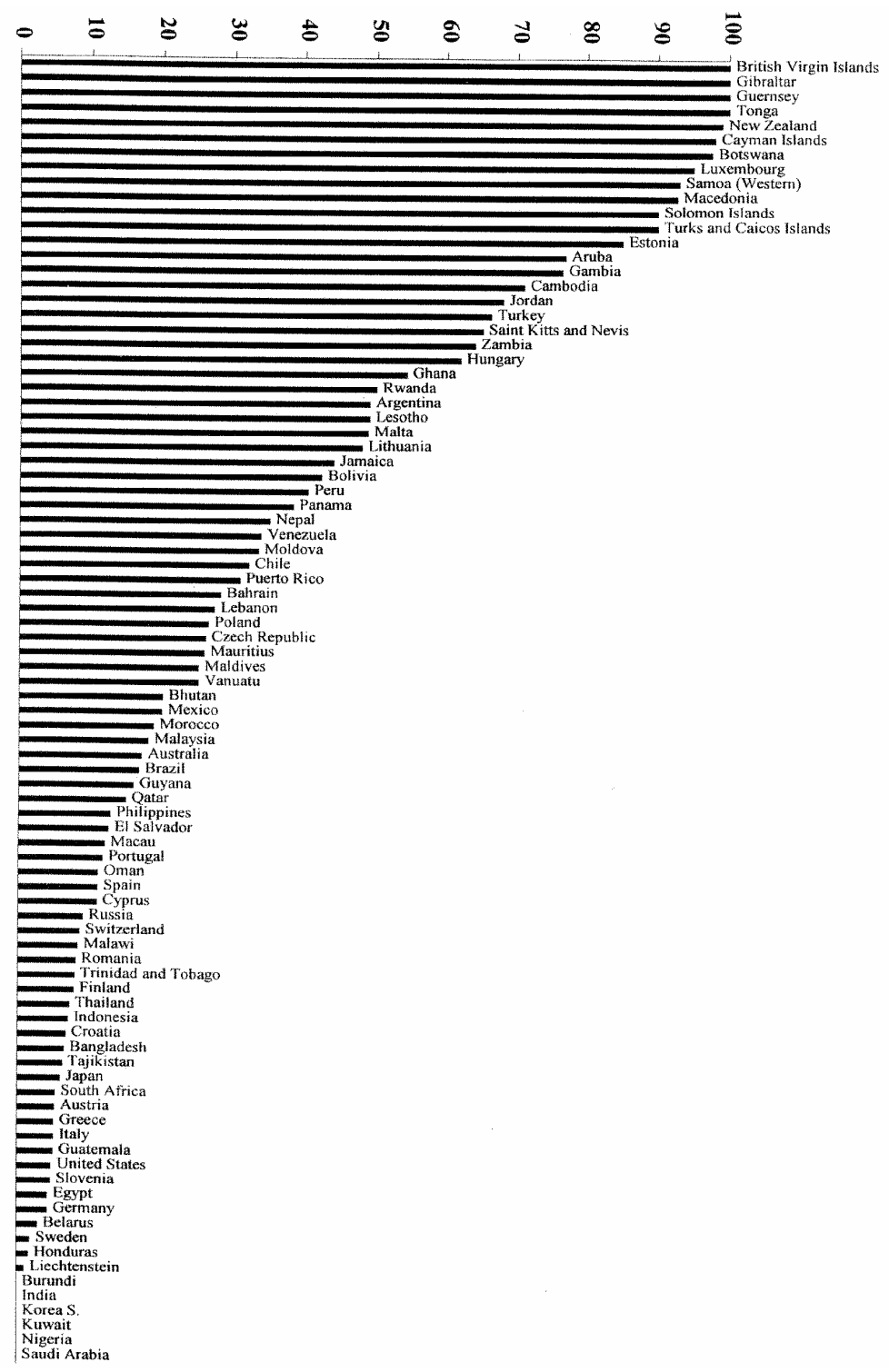

FIGURE 4.-Percent of Total Bank Assets Foreign Owned ${ }^{4}$

4. Source: Barth et al. (2001); appendix. 
The relative importance of the two channels varies greatly from country to country. This may be seen in table 4 for select countries. Banking markets tend to be more important in emerging economies. Thus, these countries should be encouraged to develop their capital markets further.

However, banks and the capital markets are not perfect substitutes. All borrowers cannot obtain credit on the capital market on equal terms as from banks. In particular, smaller borrowers or those that require the details of the financing to be uniquely tailored to their needs may find financing on the capital markets less available and more expensive.

In addition, the existence of a viable capital market tends to promote competition that should force banks to be more efficient; see Kaufman and Kroszner (1997). Economies that have both financing channels appear to grow faster than economies that have only one operating channel; see Levine (1997a). It is also important to maintain competition within each channel as well as between the two channels. The evidence suggests that many countries which have only a banking channel and great concentration in banking have seen the development of their capital markets retarded by the excessive economic and political power wielded by the banks. Permitting foreign banks to enter, particularly through buying existing insolvent SOBs, would not only increase competition among banks but also increase capitalization and reduce the likelihood of credit crunches. But, as can be seen from figure 4, countries differ greatly in their willingness to permit entry of foreign banks.

\section{F. Reduce Corporate Leverage}

The higher is the leverage (lower is capital) of an entity, the smaller need be an adverse shock to drive it into economic insolvency. This is true for nonbank firms as well as for banks. Leverage ratios in many emerging economies tend to be far higher, on average, than in developed countries and, because their macro instability tends also to be greater, the probability of insolvency is high. The higher leverage ratios appear to reflect both the looser credit standards of banks in these countries and the existence of implicit guarantees of some of the debt and, at times, even the equity of stakeholders in these firms by the government. Thus, the bondholders tend to be lax on requiring a greater junior equity cushion. In addition, in many of these countries, the legal bankruptcy provisions are vague and unenforced and insolvencies are not resolved or the firms are restructured inefficiently. Thus, the penalty for insolvency is small and banks and other firms alike move out on their 
risk function and substitute debt for equity. Resources are mis-allocated, aggregate output is reduced and, to the extent that the leverage is higher than would be permitted by the market without government guarantees given the nature of the macro-shocks, the economy is more vulnerable to breakdown.

Leverage ratios may be expected to be reduced if governments explicitly remove their perceived guarantees and strengthened their bankruptcy provisions and enforcement. Losses as well as profits would then be privatized rather than socialized. This would reduce the macro instability from external shocks, encourage bank lending based on credit analysis, and improve the allocation of resources, increasing aggregate output and stability.

\section{V.Summary and Conclusions}

Macro and banking stability are closely linked, so that what happens in one affects the other. The evidence for most countries suggests that, except where the banks are state owned or heavily state controlled, instability generally starts in the macro-economy and spills over into the banking sector. The resulting banking instability, in turn, feeds back and amplifies the macro instability. Thus, to enhance overall stability in the economy, it is necessary both to pursue successful contra-cyclical macroeconomic policy and to reduce the fragility of banking relative to the magnitude of macro shocks that may be expected in the particular economy. This paper focuses on how to stabilize the banking system.

The paper argues that, in the absence of government intervention, either directly through ownership or heavy control or indirectly through safety-nets under banks, banking is not inherently unstable or fragile and does not generally ignite downturns in the macro-economy. But once the government intervenes in either way, fragility and instability increases. Banks decrease their capital ratios and increase the risk exposure of their asset and liability portfolios beyond what they would have been in the absence of the intervention. Thus, they are likely to become economically insolvent more often and, more importantly, able to continue in operation after insolvency as depositors perceive their funds to be guaranteed by the government and do not run. This provides the institution the ability to continue to generate losses and the regulators the ability to delay resolution and thereby, on average, increase the cost of the failures to the taxpayers. At some point of time, 
as these losses increase, the ability of the government to service its ever increasing debt, including the deposits at insolvent banks that exceed the value of the assets, decreases and the government looses its credibility. At that point, the insolvency of the banks can no longer be disguised and will be officially recognized and booked. This event is likely to start long overdue corrections in the macro-economy, which also are likely to be more painful than if started sooner.

The paper concludes by enumerating a number of lessons for achieving bank stability, including the design of optimum regulatory structures. Perhaps the most important is to pursue appropriate national contra-cyclical monetary and fiscal policy, but not contra-cyclical prudential regulatory policy. The latter tends to operate contrary to the way market forces operate and, although possibly politically popular, only amplify the long-run costs of banking crises and the instability in the macro-economy. The paper describes a system of prudential regulation that has been adopted in the U.S. to mimic market discipline in the presence of a government safety-net. But the effectiveness of particular prudential policies is country specific and their design must take into account the presence or absence of a number of important preconditions, including the credibility of the government; the availability of a well-trained, well-compensated and well-respected bank supervisors; a functioning legal system that provides for efficient bankruptcy and property rights; and a credit and equity culture that privatizes bank losses as well as gains.

The paper also supports liberalizations of regulations and prohibitions that interfere with efficient operations of banks and financial markets, but emphasizes that the process of liberalization is as important as the ultimate goal. If the process is undertaken poorly, the results before the new equilibriums are reached may well be less efficient and more costly than the inefficiencies that deregulation was intended to replace in the first place. Lastly, the paper recommends procedures for minimizing any loss of liquidity when banks fail, privatizing SOBs and SCBs, and reducing leverage both for banks and other entities, so that their vulnerability to macro shocks is no greater than it would be in the absence of any explicit or implicit government guarantees. Indeed, maximizing macro-stability requires both good macro monetary and fiscal policies and prudential policies towards banks and other entities in financial markets that permit market discipline to correct imbalances before they are permitted to accumulate. This may result in an economy with a larger number but 
milder banking and macro adjustments relative to what would occur in an economy that attempts to shelter its banks and financial sector from such discipline. The latter economies are likely to have fewer but much larger, longer, and more costly crises. That is, market failures are likely to be more frequent but less damaging than regulatory failures.

\section{References}

Barth, J. R.; Caprio G.; and Levine R. 2001. Bank regulation and supervision: What works and what doesn't. Working paper (February). Brookings: Wharton Conference on Financial Services.

Benston, G. J.; Eisenbeis, R. A.; Horvitz, P. M.; Kane, E. J.; and Kaufman, G. G. 1986. Perspectives on safe and sound banking. Cambridge, MA: MIT Press.

Benston, G. J. and Kaufman, G. G. 1995. Is the banking and payments system fragile? Journal of Financial Services Research (December): 209-240.

Bliss, R. and Kaufman, G. G. 2003. Bank procyclicality, credit crunches, and asymmetric monetary policy effects. Journal of Applied Finance (Fall/Winter): 23-31.

Bordo, M.; Eichengreen, B.; Klingebiel, D.; and Martinez-Peria, M. S. 2001. Financial crises: Lessons from the last 120 years. Economic Policy (April).

Borio, C.; Furfine, C.; and Lowe, P. 2001. Procyclicality of financial system and financial stability. Marrying the macro-and-micro-prudential dimensions of financial stability. BIS papers No. 1. (March). Basel: Bank for International Settlements.

Calomiris, C. W. 1999. Runs on banks and the lesson of the great depression. Regulation 22 (1): 4-7.

Dermine, J. 1996. Comment. Swiss Journal of Economics and Statistics (December): 679-682.

Eichengreen, B. and Arteta, C. 2000. Banking crises in emerging countries. Working paper: University of California at Berkeley.

Greenspan, A. 1998. Remarks at annual convention of the independent bankers association of America. (March 3). Washington, D.C.: Board of Governors of the Federal Reserve System.

Honohan, P. and Klingebiel, D. 2003. The fiscal cost implications of an accommodating approach to banking crises. Journal of Banking and Finance (August): 1539-1560.

Kaminsky, G. L. and Reinhart, C. 1996. The twin crises: The causes of banking and balance-of-payments Problem. International Finance Discussion Papers 1996-544. Washington, D.C.: Board of Governors of the Federal Reserve System.

Kane, E. J. and Klingebiel, D. 2004. Alternatives to blanket guarantees for 
containing a systemic crisis. Journal of Financial Stability (September): 3163.

Kaufman, G. G. 1995. The U.S. banking debacle of the 1980s: An overview and lessons. The Financier (May): 9-26.

Kaufman, G. G. 1996. Bank fragility: Perception and historical evidence. Working paper series (September) 96-18: Federal Reserve Bank of Chicago.

Kaufman, G. G. 1997. Lessons for transitional and developing economies from U.S. deposit insurance reform. In George M. von Fursenberg (ed). Regulation and Supervision of Financial Institutions in the NAFTA Countries and Beyond. Boston: Kluwer Academic: 16-35.

Kaufman, G. G. 1999. Resolving, recapitalizing, and restructuring insolvent banks and banking systems. In Benton E. Gup (ed). International Banking Crises. Wesport, CT: Quorum Books: 264-286.

Kaufman, G. G. 2000. Preventing bank crises: Taking the 'state' out of state banks. 252-266. In D. Papadimitriou (eds). Modernizing Financial Systems. New York: St. Martin's Press.

Kaufman, G. G. 2004. Basel II: The roar that moused. In Benton Gup (ed). The New Basel Capital Accord (forthcoming). Cincinnati: South-Western/ Thomson.

Kaufman, G. G. and Kroszner, R. S. 1997. How should financial institutions and markets be structured: Options for financial system design. In L. RojasSuarez (ed). Safe and Sound Financial Systems. Washington, D.C.: Inter-American Development Bank: 97-122.

Kaufman, G. G. and Seelig, S. A. 2002. Post-resolution treatment of depositors at failed banks. Economic Perspectives (Second Quarter): Federal Reserve Bank of Chicago: 27- 41.

Levine, R. 1997a. Stock markets, economic development and capital control liberalization. Perspective (December): Investment Company Institute.

Levine, R. 1997b. Financial development and economic growth: Views and agenda. Journal of Economic Literature (June): 6887-26. 